лексические единицы (например, авторские антропонимы) могут быть переданы путём калькирования.

1. Верещагин Е. М., Костомаров В. Г. Язык и культура. М.: Русский язык, 2000. 387 с.

2. Иванов А. О. Безэквивалентная лексика. СПб.: Типография издательства СПбГУ, 2006. 200 с.

3. Комиссаров В. Н. Теория перевода. М.: Прогресс, 2000. 253 с.

4. Маркес Г. Г. Сто лет одиночества: Книга для чтения на испанском языке. СПб.: КОРОНА принт; KAPO, 2004. $416 \mathrm{c}$.

5. Маркес Г. Г. Сто лет одиночества. Полковнику никто не пишет: Пер. с исп. М.: Правда, 1986. 480 c.

6. Топоркова Ю. А. Способы передачи безэквивалентной лексики романа Г. Г. Маркеса «Сто лет одиночества» в русском переводе // Филологические науки. Вопросы теории и практики, 2017. № 8-1 (74). C. $151-153$.

\title{
Moiseeva A.V. Revisiting the problems of text perception
}

Bashkir State University

(Russia, Ufa)

doi: $10.18411 / l j-01-2021-228$

idsp: ljournal-01-2021-228

\section{Аннотация}

В статье рассматриваются феномен восприятия письменного текста, исходя из позиции активности воспринимающего субъекта, целенаправленности восприятия, а также его зависимости от многих факторов (в том числе от мотивации, сопутствующих обстоятельств, предшествующего опыта и его организации в долговременной памяти и т.д.).

Ключевые слова: восприятие, цельность, связность, осмысление, интерпретация текста.

\section{Abstract}

The article examines the phenomenon of perception of a written text proceeding from the active position of the perceiving person, the purposefulness of perception, as well as its dependence on many factors (including motivation, accompanying circumstances, previous experience and its organization in long-term memory, etc.).

Key words: perception, integrity, coherence, comprehension, interpretation of the text.

Currently, any linguistic research in which the author refers to the text (orally or in writing) as the main unit of human communication or in which phenomena that go beyond the sentence are analyzed are usually considered to be the linguistics of the text, whereas fragments of the text are considered as independent linguistic units.

In psychology, the process of perception is understood as an integral reflection of objects, situations and events that occurs under the direct influence of physical irritants to the receptors of the sense organs. The resulting perceptual image is subjected to verification and correction during practical activities, communication and research.

Viewing the perception of speech as "processing", semantic interpretation of the text, in which the image of the text is created, is a necessary compositional part of the overall process of perception. The perception of speech involves person's perceptual system, and therefore it is subject to the laws of general physiology of perception [Vasilieva et al. 1995: 23]. 
One of the first challenges faced by scientists dealing with problems of perception of a language message is the problem of isolating perceptual units. In this regard, A.S. Stern mentions two hypotheses that allow to define approaches to the definition of mechanisms of perception. According to the first hypothesis mechanisms of perception of meaningless and meaningful segments of speech are fundamentally different, and in this case we can only speak about the perceptual aspect of perception in terms of syllables. According to the second hypothesis, there is a general mechanism for speech segments at all linguistic levels, and it is this entity that proves, according to the author, the existence of perception as a necessary level of speech perception as a whole [Stern 1992: 185].

If you accept a simplified scheme, according to which three levels are distinguished in speech perception - sensory (sound), perceptual (verbal) and semantic (level of sentences and texts), then it can be assumed that perceiving the text in different degrees will involve all three levels [Stern 1992: 4].

However, as experimental studies show, when perceiving the text it is also necessary to take into account the influence of two most important properties of the text - integrity and coherence. The level pattern of integrity and coherence is different. It is characteristic of integrity to correlate with the depth of perception, that is, a kind of movement from top to bottom, vertically. For coherence, it is noteworthy to correlate with the hierarchy of linguistic levels, at each of which there are linear dependencies [Stern 1992: 202].

The researches show that in a number of cases it is appropriate to talk about inter level situations of perception. For example, when recognizing a word, it is most often comprehended, this is evidenced by difficulties in the perception of unfamiliar or very rare words. Thus, here we can talk about the perceptual-semantic level. And not without reason the researchers speak of the "presumption of meaningfulness" [Kasevich 1988: 249], that is, "the urge to comprehension ", which manifests itself even when the recipients in the experiment are offered to identify meaningless language material. The person tries to give a certain meaning to the juxtaposed audio segments in any case, even if there is no semantic connection between them [Stern 1992: 5].

When the text is perceived, the perception of its constituent words also occurs.

Consequently, the standards of words stored in the linguistic memory of native speakers participate in perception of coherent text. At the same time, sound standards are also stored in memory (or syllables), as evidenced by the data of numerous studies. In this way, boundaries between three levels of perception - sensory, perceptual and semantic - turn out to be blurred both "from above" (between semantic and perceptual) and "from below" (between sensory and perceptual) [Stern 1992: 202].

The next question that arises when describing the process of text perception is a question about the strategy of perception. Relatively recently, there was only one hypothesis: stages of perception are ordered from the bottom up, when a person first recodes the incoming acoustic information into a chain of discrete elements - phonemes, then the phonemes are organized into some blocks corresponding exponents of words (or morphemes), syntactic links are established between them and in the end, the meaning of the statement becomes clear [Kasevich 1988: 245].

However, as applied to the text, the possibility of another strategy cannot be ruled out, when the stages of this process are ordered from top to bottom.

This is dictated by the fact that the phonemic perception, which underlies the "ascending model ", can't be applied on a full-scale basis due to the limited resolution ability of the human auditory analyzer. Therefore, there must be a mechanism that provides quantization of the speech stream into larger segments than a phoneme. The word is recognized as such an enlarged unit of perception [Kasevich 1988: 245-246].

V. B. Kasevich generally prefers to talk about the combination of two perception strategies: of descending and ascending character. In his opinion, simultaneously with the recognition of the word as the unit, with which the hearer deals first of all, one has to admit 
that, at least for this part of perceptual processes, the movement from a higher-level unit (word) to a lower-level unit (phoneme) is also typical. He also recognizes the possibility of a broader reading of the concept top-down perception: “... the process of perception generally begins with a hypothesis about the semantic characteristics of the perceived utterance, then this hypothesis is verified and concretized by referring to information about the properties, characteristics of units of the lower levels "[Kasevich 1988: 248]. Wherein V. B. Katsevich reminds that the text by its nature is a dynamic object, it unfolds in time, therefore the perception must certainly be flowing. According to his words, "at any given moment in time, the listener is dealing with some fragment of the text in process of formation, while the whole object (the text) as a whole is subject to recognition" [Kasevich 1988: 248].

Due to the fact that a person is able to perceive the text of unlimited length, speech perception cannot be exclusively top-down.

The unit of perception cannot be an integral text of an indefinitely large volume, the semantic structure of such a text will be "assembled" from fragmentary semantic structures that are currently recognized. And this, according to V. B. Kasevich, means that a combination of descending and ascending perception is necessary [Kasevich 1988: 250].

According to T. van Dijk and V. Kinch understanding, starting with words, moves on to sentences, then to groups of sentences and the highest structures of text, or macrostructures [Kintsch, van Dijk 1983].

The results of V. Kinch's research reveal differences in the understanding of texts with the same superficial structure, but a different number of propositions, which consist, in particular, in the amount of time required for understanding [Kintch 1979].

When considering the model of understanding, T. van Dijk and V. Kinch distinguish between the propositional model that participates in the representation of the text and the situational model that encompasses the knowledge already possessed by the recipient, as well as the information obtained from the text.

Thus, the mentioned model considers the process of text understanding as a set of reflection of the text base and the functioning of the situation model (presentation of events and facts described in the text).

The strategic model of $\mathrm{V}$. Kinch and $\mathrm{T}$. van Dijk uses the following strategies: propositional; macro strategies that determine the main topic of the text; local connectivity strategies that ensure the connection between the parts of the text; production strategies responsible for producing discourse in response to the author's discourse; stylistic, offering a variety of ways of expressing the same meaning depending on the type of text and functionally pragmatic orientation.

The complexity of the process of understanding involves the actualization of some of the principles operating in the process of interpreting the text. Among them are the knowledge of the recipients involved in text understanding, the ability to apply them in modeling of the situation, the memory capacity, the goals of the communication participants, the communicative orientation of the text. It should be noted that the situational model containing the knowledge and personal experience of subjects of communication undergoes transformation in the process of perceiving the text.

The strategic model of T.A. van Dijk and W. Kinch contains several levels of representation processing involved in the text understanding: 1) sensory register, 2) long-term memory, 3) episodic textual memory, in which surface memory, propositional text base, macrostructure (general content of the text) and model of the situation can be marked out [Dijk, Kinch 1988].

According to the authors of the model, "understanding is no longer just a passive construction of the representation of a linguistic object, but a part of an interactive process in which the listener actively interprets the actions of the speaker" [Dijk, Kintsch 1988: 34]. Consequently, different recipients will have differences in the interpretation of the original 
written message. Thus, the content laid down in the text by the author may differ from the content extracted by the recipient, in accordance with his motives and goals [ibid.].

An important feature of the T.A. van Dijk and W. Kinch's model is the ability to interpret the text in many ways. The creators of the model represent the process of understanding as a multilevel formation. Views based on disparate data are processed first; hence is the unstructured nature of understanding. At the next levels, views become more well-structured. However, primary perception gives rise to discrepancies in interpretation, which is reflected at the level of comprehension. The key propositions for further processing of the text are fixed in memory, while the secondary ones provide the variability of the formed representations [Dijk, Kinch 1988].

In the process of understanding, there is a transition to the image of the content of the text, while perception can be considered a stage preceding the process of understanding. N.P. Peshkova notes that in reality "these stages can occur simultaneously, intertwining, and overlapping each other" [Peshkova 2015: 210].

\section{***}

1. Vasilyeva N.V., Vinogradov V.A., Shakhnarovich A.M. A short dictionary of linguistic terms. M .: Russian language, 2003.

2. Dijk van T.A., Kinch W. Strategies for understanding a coherent text // New in foreign linguistics. 1988. - Issue 23. - P. 153-207.

3. Dijk van T.A., Kintch W. Strategies of Discourse Comprehension. - New York, 1983. - 427 p.

4. Kasevich V.B. Semantics. Syntax. Morphology. - M.: Nauka, 1988. - 309 p.

5. Kintsch W. On Modeling Comprehension// Educational Psychologist. 1979. - Issue 14. - P. 3-14.

6. Peshkova N.P. Typology of Scientific Text: Psycholinguistic Aspect. - Ufa: RITs BashGU, 2015. - 292 p.

7. Shtern A.S. Perceptual aspect of speech activity. - SPb: SPbGU, 1992. - 286 p. 